«Системні технологіï» 2 (133) 2021 «System technologies»

DOI 10.34185/1562-9945-2-133-2021-07

УДК 621-83 681.51

Г.Ю. Станчиц, А.Г.Станчиц, О.В. Румянцев

\title{
ДОСЛІДЖЕННЯ БАГАТОКАНЛЬНИХ СИСТЕМ ПОЧЕРГОВОГО КЕРУВАННЯ
}

Анотація. Розглядаються багатоканальні системи керування, в яких керуючий вплив, прикладається в одному з каналів, відповідно до деякого закону перемикання. Приведена класифікація багатоканальних систем почергового керування (БСПК). Приведені різні типові схеми БСПК і приведений їх порівняльний аналіз. Розглядаються різні умови перемикання керуючого впливу. Приведена цифрова імітаційна модель БСПК і результати їі досліджень.

У багатьох випадках системи автоматичного керування (САК) мають складну структуру і велике число в різному ступені пов'язаних між собою каналів керування. У числі цих САК існують такі системи, в яких в кожному з каналів керування використовується один загальний для усіх каналів виконавський або вирішальний елемент. Залежно від типу загального елементу можна виділити три класи таких систем.

1. Ергатичні системи, що включають оператора і декілька керованих ним об'єктів.

2. Автоматизовані системи керування з EOM, що по черзі підключається до різних блоків системи.

3. Системи автоматичного керування з одним виконавчим органом.

В якості систем, останньою з названих класів, можна привести САК космічного апарату з поворотними реактивними соплами. В цьому випадку керування орієнтацією космічного апарату відносно кожної з трьох ортогональних пов'язаних $з$ апаратом осей робиться по черзі. Для цього сопла розгортаються у відповідну площину при виконанні деяких умов, що називаються умовами перемикання.

Інший приклад - багатоканальна система, кожен канал якої оснащений виконавчим органом (ВО), але одночасне включення ВО неможливе із-за взаємного впливу включених ВО, що призводить до негативного ефекту, або через нестачу енергії. Таким чином, для систем вказаного класу передбачається, що

(C) Станчиц Г.Ю., Станчиц А.Г., Румянцев О.В., 2021 


\section{«Системні технології» 2 (133) 2021 «System technologies»}

одночасне формування дій, що управляють, в каналах керування неможливе. Канал в якому необхідно здійснювати керування, визначається за допомогою законів перемикання, вид яких обумовлений вирішуваною задачею.

Дослідження проводилися за допомогою комп'ютерної симуляції для різних законів перемикання каналів, і законів формування дії, що управляє, в кожному каналі системи. Основний вплив обернений на вивчення особливостей даних систем, пов'язаних з необхідністю включення лише одного з каналів системи керування.

Типові структурні схеми, багатоканальних систем почергового керування. Закони перемикання каналів задаються за допомогою деяких функцій $\mathrm{F}\left(\mathrm{x}_{\mathrm{ij}}, \Delta_{\mathrm{ij}}, \mathrm{t}\right)$, де $\mathrm{x}_{\mathrm{ij}}$ - різні параметри системи; $\Delta_{\mathrm{ij}}$ - крок перемикання каналів управління; $\mathrm{t}$ - час; $\mathrm{i}, \mathrm{j}$ - індекси каналів управління і регульованих параметрів відповідно. Перемикання загального елемента 3 каналу в канал відбувається після досягнення функцією $\mathrm{F}\left(\mathrm{x}_{\mathrm{ij},}, \Delta_{\mathrm{i}}, \mathrm{t}\right)$ заданої величини або звернення її в нуль. Використання останніх умов призводить до умов перемикання каналів, за допомогою яких визначаються моменти перемикання загального елемента 3 каналу в канал.

Залежно від виду закону перемикання можна виділити кілька структурних схем багатоканальних систем почергового керування (БСПК), які наведено на Рисунках $1-4$.

У першому випадку функція визначає умови перемикання каналів має вигляд $\mathrm{F}\left(\mathrm{x}_{\mathrm{ij}}\right)$, у другому $-\mathrm{F}(\mathrm{t})$, в третьому $-\mathrm{F}\left(\mathrm{x}_{\mathrm{i}}, \mathrm{t}\right)$ i в четвертому $-\mathrm{F}\left(\mathrm{x}_{\mathrm{ij}}, \Delta_{\mathrm{ij}}\right)$.

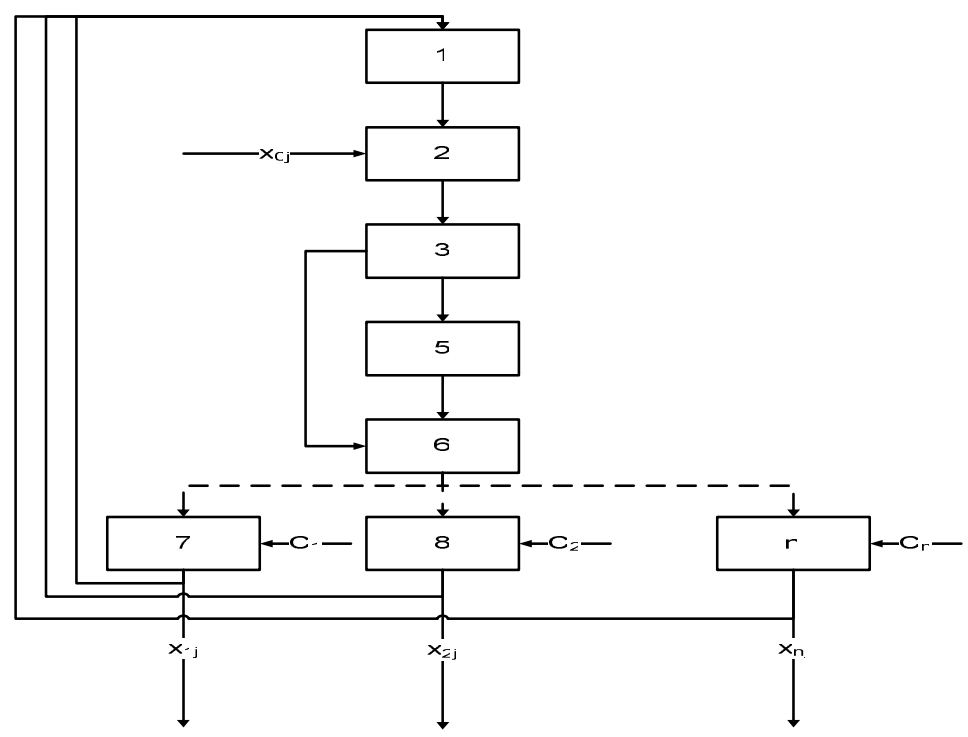

1 - блок керування; 2 - пристрій порівняння $3 \mathbf{x}_{0 j} ; 3$ - пристрій порівняння; 5 виконавчий орган; 6 - пристрій комутації; 7, 8, .., n - вплив зовнішніх збурень.

Рисунок 1 - Схема БСПК з умовою перемикання $\mathrm{F}\left(\mathrm{x}_{\mathrm{ij}}\right)$ 
«Системні технології» 2 (133) 2021 «System technologies»

Розглянемо роботу БСПК, схема якої приведена на Рисунку 1.1. Визначення і перетворення в сигнали регульованих параметрів $\mathbf{x}_{\mathbf{i j}}$ проводиться в блоці керування 1 , після чого ці сигнали порівнюються з граничним значенням $\mathbf{x}_{0 \mathbf{j}}$ на пристрої порівняння 2. Якщо поточні значення перевищують порогові, то сигнали надходять на пристрій порівняння 3, де визначається канал 3 максимальним по модулю поточним значенням регульованого параметра. Сигнал який відповідає максимальному по модулю значенню надійде на виконавчий орган 5 , який за допомогою пристрою комутації 6 , по команді пристрою порівняння 3, підключиться до відповідного каналу керування.

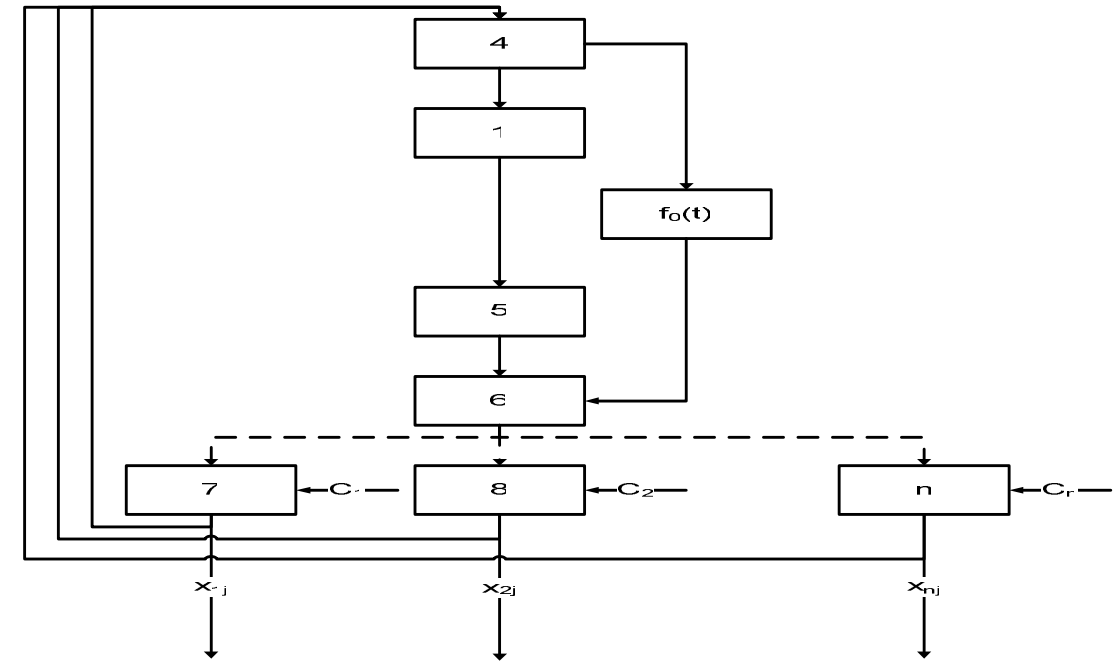

1 - блок керування; 4, 6 - пристрої комутації; 5 - виконавчий орган; 7, 8, .., $\mathrm{n}$ - вплив зовнішніх збурень.

Рисунок 2 - Схема БСПК з умовою перемикання $\mathrm{F}(\mathrm{t})$

Для БСПК (Рисунок 2) характерна наявність двох синхронно працюючих комутуючих пристроїв 4 i 6 , які за заданою тимчасовою програмою $\mathrm{f}_{0}(\mathrm{t})$ по черзі підключають блок керування 1 та виконавчий орган 5 до каналів керування 7,8 ... n. Програма $\mathrm{f}(\mathrm{t})$ може формуватися зокрема, відповідно до величин зовнішніх збурень $\mathrm{C}_{\mathrm{i}}$. 
«Системні технологіï» 2 (133) 2021 «System technologies»

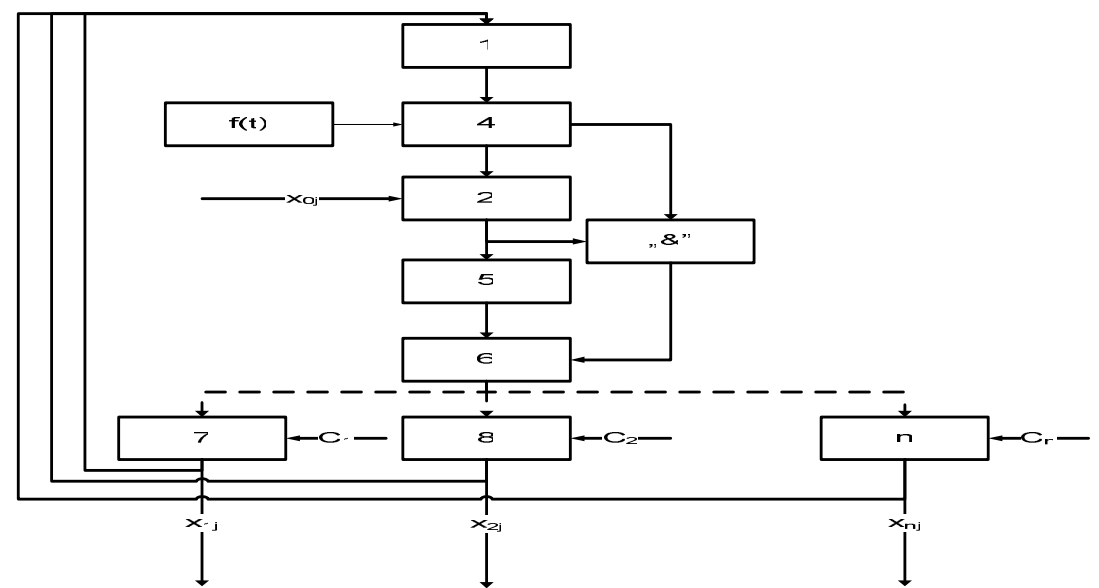

1 - блок керування; 2 - пристрій порівняння $3 \mathrm{x}_{0 j} ; 4,6$ - пристрої комутації; 5 виконавчий орган; $7,8, . ., \mathrm{n}$ - вплив зовнішніх збурень.

Рисунок 3 - Схема БСПК з умовою перемикання $\mathrm{F}\left(\mathrm{x}_{\mathrm{ij}}, \mathrm{t}\right)$

БСПК, схема, якої представлена на Рисунку 3, працює наступним чином: сигнали, відповідні регульованим параметрам, надходять на комутуючий пристрій 4. Цей пристрій за деякою тимчасовою програмою $\mathrm{f}_{0}(\mathrm{t})$, здійснює підключення каналів керування до пристрою порівняння 2 , де поточне значення регульованого параметра порівнюється з граничним значенням хор. Якщо поточне значення перевершує по модулю допустиме, то сигнал надходить на виконавчий орган 5, який комутуючим пристроєм 6 підключається до відповідного каналу керування.

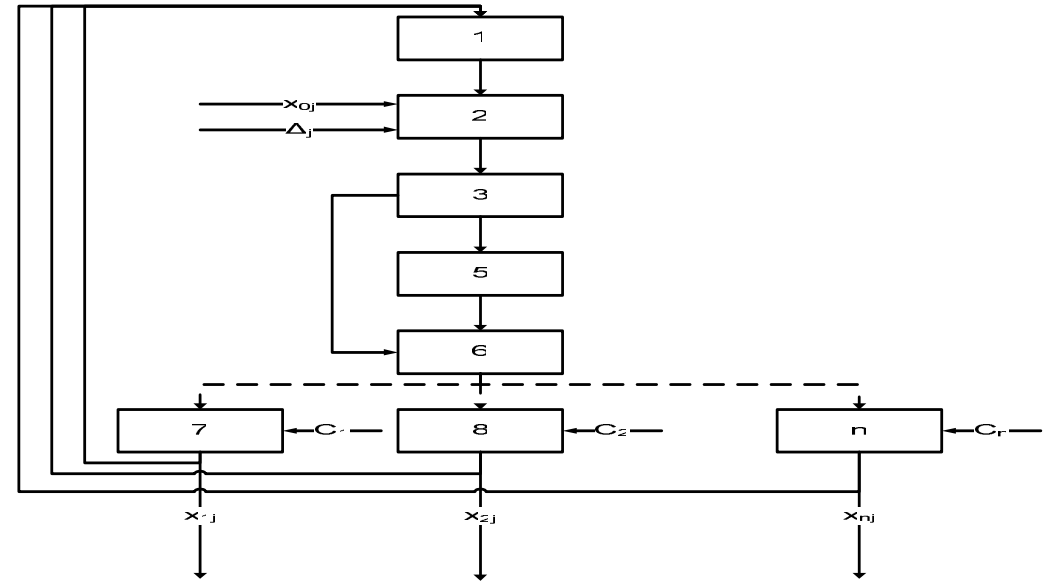

1 - блок керування; 2 - пристрій порівняння $3 \mathrm{x}_{0 j} ; 3$ - пристрій порівняння; 5 виконавчий орган; 6 - пристрій комутації; 7, 8, .., n - вплив зовнішніх збурень.

Рисунок 4 - Схема БСПК з умовою перемикання $\mathrm{F}\left(\mathrm{x}_{\mathrm{ij}}, \Delta_{\mathrm{ij}}\right)$

Для БСПК (Рисунок 4) характерна наявність такого параметру, як крок перемикання керуючого впливу, з каналу в канал $\Delta_{\mathrm{j}}$. Тобто при включенні БСПК 
«Системні технології» 2 (133) 2021 «System technologies»

виконавчий орган 5 підключається до одного 3 n-каналів (нехай $\mathrm{i}=\mathrm{k}$ ) i система залишається в цьому стані до тих пір, поки величина регульованого параметра $\mathbf{x}_{\mathrm{ij}}$ якогось іншого каналу управління (нехай $\mathrm{i}=\mathrm{m}$ ) не перевищить по модулю на величину $\Delta_{\mathbf{j}}$ величину регульованого параметра $\mathbf{x}_{\mathbf{i j}}$.

Слід зазначити, що БСПК, схеми яких наведені на Рисунках 1-3, мають ряд недоліків. Зокрема БСПК (Рисунок 1) працює з великим числом короткочасних підключень виконавчого органу до каналів керування, а системи, схеми яких дано на Рисунках 2-3, мають невисоку точність і швидкодію, внаслідок того, що функція, яка визначає умови перемикання керуючого впливу з каналу в канал, $€$ функцією часу.

БСПК, схема якої представлена на Рисунку 4, позбавлена вищеназваних недоліків, Тому краще будувати БСПК за цією схемою.

Для БСПК, як і для САК інших класів, необхідно вирішувати задачу забезпечення стійкості і заданої якості керування. Відмінною рисою БСПК є наявність двох законів керування, один з яких відноситься до керування включенням загального елемента, а інший - до керування у відповідному каналі.

Розглянемо БСПК, робота якої описується системою звичайних диференціальних рівнянь.

$$
\left\{\begin{array}{c}
y_{i}=a_{i} y_{i}+b_{i} x_{i}+c_{i}+d_{i} R_{i} \\
x_{i}=y_{i} \quad(i=1,2,3 \ldots n)
\end{array} ;\right.
$$

де $x_{i}$ - регульований параметр;

$c_{i} \mathrm{i} d_{i}-$ зовнішнє збурення та керуюча дія. Причому вони пов'язані співвідношенням $c_{i}=\square \cdot d_{i}$, де $\square-$ коефіцієнт пропорційності, який змінюється в діапазоні $0 \div 1$.

Керуюча дія може мати різний вигляд для різних законів керування: пропорційного

a) $d_{i}=-d_{0} \cdot x_{i}$,

б) $\mathbf{d}_{\mathrm{i}}=-\mathbf{d}_{0}\left(\mathbf{x}_{\mathrm{i}}+\mathbf{k \mathbf { x } _ { 1 } )}\right.$.

релейного

a) $d_{i}=-d_{0} \cdot \operatorname{sign} x_{i}$.

б) $d_{i}=-d_{0}=\operatorname{sign}\left(x_{i}+k x_{i}^{2}\right)$.

Функція $R_{i}\left(F_{i}\right)$, що має вигляд релейної функції (із зоною нечутливості або без неї), визначається таким чином:

$$
\mathrm{R}_{\mathrm{i}}\left(\mathrm{F}_{\mathrm{i}}\right)=\left\{\begin{array}{r}
0 \text { при } \mathrm{F}_{\mathrm{i}}<0 \\
1 \text { при } \mathrm{F}_{\mathrm{i}}>\Delta
\end{array}\right.
$$


«Системні технології» 2 (133) 2021 «System technologies»

де $\Delta$ - деяке позитивне число, або нуль.

Для приведених вище типових схем БСПК, функції, що визначають умови перемикання загального елементу системи, мають вигляд: для схеми, приведеної на Рисунку 1

$$
\begin{aligned}
& \text { 1) } F_{i}\left(x_{i}\right)=\left|x_{k}\right|-\left|x_{i}\right|, \\
& \text { 2) } F_{i}\left(x_{i}, y_{i}\right)=\left|x_{k}+k_{1} y_{k}\right|-\left|x_{i}+k_{1} y_{i}\right|,
\end{aligned}
$$

де $i=1,2,3, \ldots n$;

$$
\begin{aligned}
& k=1,2,3, \ldots n ; \\
& i \neq k ;
\end{aligned}
$$

і для схеми, приведеної на Рисунку 2

3) $F_{i}(t)=t_{m n+i}-t$,

де

$$
\begin{aligned}
& t_{m n+i}=m \sum_{i=1}^{n} \Delta t_{i}-\sum_{k=1}^{i} \Delta t_{k} \\
& m=e n t \frac{t}{\sum_{i=1}^{n} \Delta t_{i}}, \\
& \Delta t_{i}=f\left(c_{i}\right) \\
& \text { 3) } F_{i}(t)=t_{m n+i}-t
\end{aligned}
$$

де $t_{m n+i}=(m \cdot n+i) \Delta t$.

$$
m=e n t \frac{t}{n \cdot \Delta t} \text {, }
$$

Для БСПК (Рисунок 3) умови перемикання дії, що управляє, визначаються комбінацією з приведених вище координатних (1 і 2) і тимчасових (3 і 4) функцій $F_{i}$.

Для БСПК, схема якої дана на рисунку 4, функції що задають умови перемикання керуючої дії, мають вид:

1) $F_{i}\left(x_{i}\right)=\left|x_{k}\right|-\left|x_{i}\right|$,

2) $F_{i}\left(x_{i}, y_{i}\right)=\left|x_{k}+k_{1} y_{k}\right|-\left|x_{i}+k_{1} y_{i}\right|$,

$$
\text { де } i=1,2,3, \ldots n \text {; }
$$

$$
k=1,2,3, \ldots n \text {; }
$$

$i \neq k$;

Вибір типової схеми БСПК обумовлений вимогами, що пред'являються до системи.

Комп’ютерне моделювання системи було розроблено в інтерактивному середовищі LabVIEW компанії National Instruments. Програма написана графічною мовою програмування «G», інтерпретатор якої являється невід’ємною частиною цього середовища розробки. 
«Системні технології» 2 (133) 2021 «System technologies»

-Кількість каналів керування $1 . . .5$;

- Початкове значення сигналу X[n] - $-1000 \ldots . . .1000$;

- Граничне значення сигналу Х[0] -100...100;

- Рівень зовнішнього збурення по кожному каналу -10...10;

- Максимальне значення керуючого впливу 0...100;

- Мінімальне значення керуючого впливу $0 . .-100$;

- Крок перемикання $\Delta[\mathrm{X}] \pm 0 \ldots 100$.

Лицьова панель та блок-діаграма основної програми зображені на Рисункаx 5 i 6
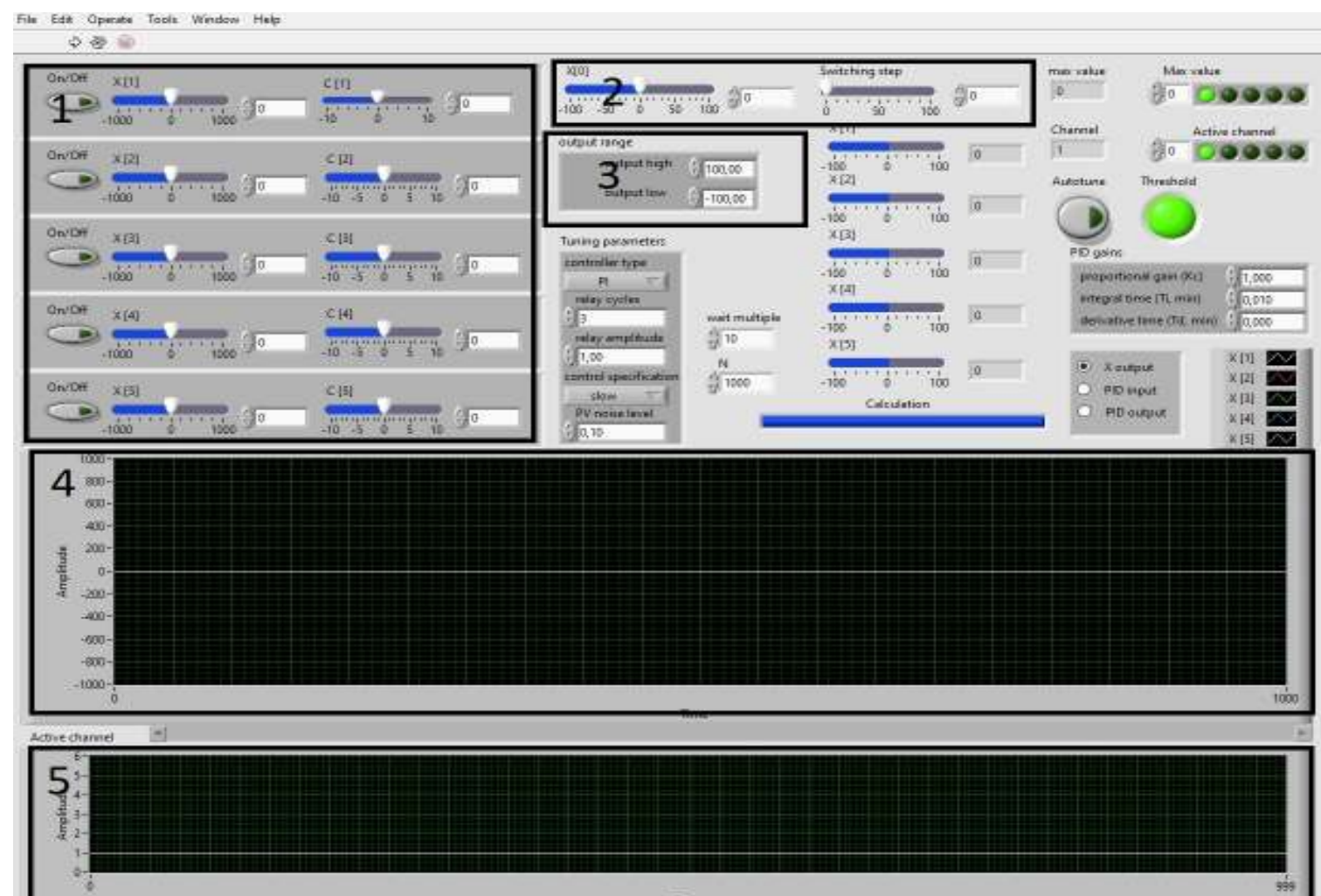

1 - початкові дані по кожному каналу; 2 - граничне значення та крок перемикання; 3 - керуючий вплив; 4 - вихідні дані; 5 - активний канал.

Рисунок 5 - Лицьова панель програми

На лицьовій панелі в блоках 1,2 і 3 задаємо параметри системи для дослідження, на графіках 4 і 5 спостерігаємо результати симуляції. 
«Системні технології» 2 (133) 2021 «System technologies»

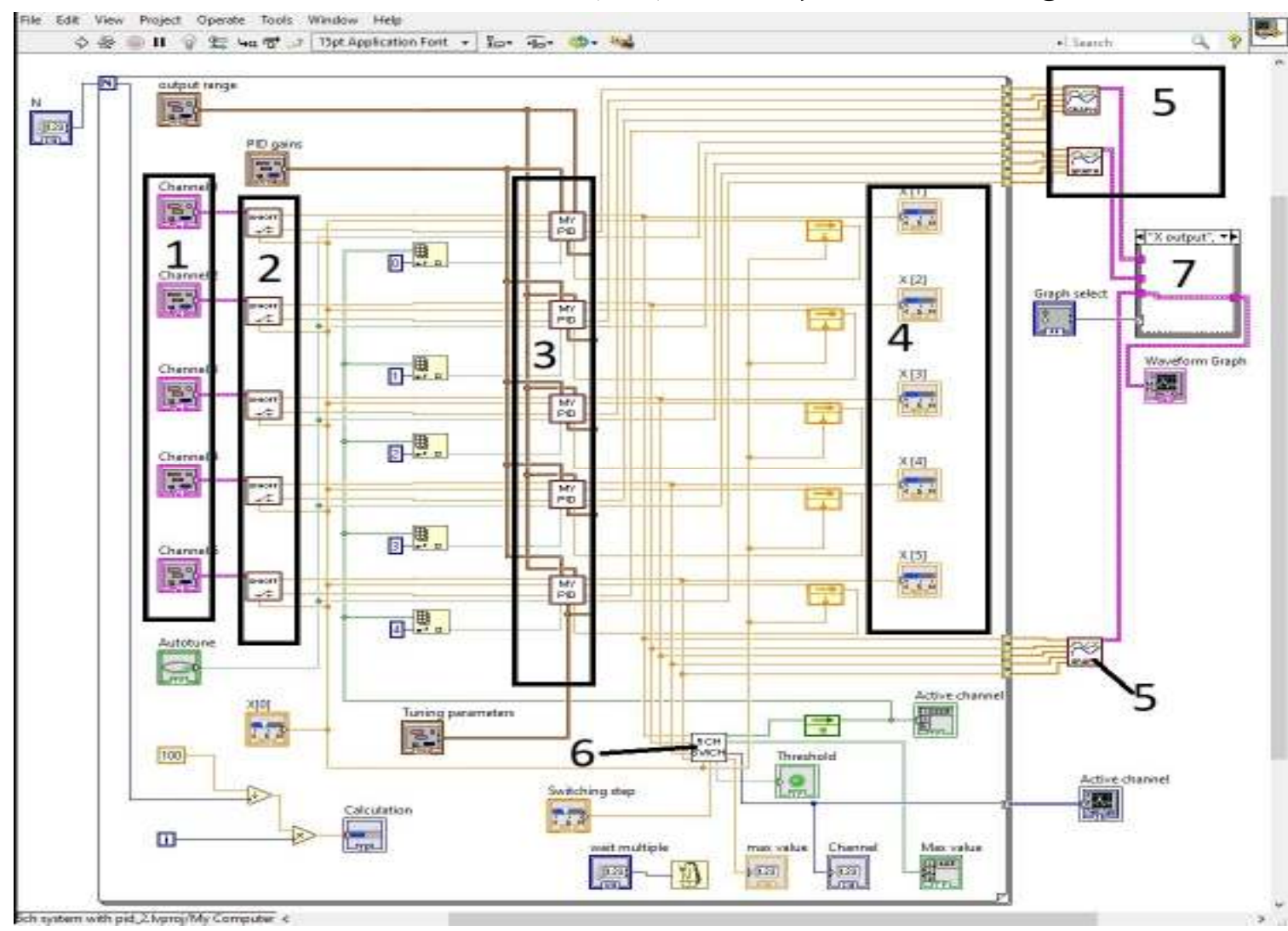

1 - початкові дані по кожному каналу; 2 - блок активації каналу даних; 3 блоки регулювання; 4 - вихідні дані; 5 - блоки формування вихідного графіка; 6 - блок порівняння та перемикання керуючого впливу; 7 - перемикання даних для відображення.

Рисунок 6 - Блок-діаграма програми

Симуляція роботи системі в режимі реального часу утворена за допомогою циклічної структури «For-loop» 1000 ітерацій з інтервалом 10мс, але за потреби ці параметри можна змінити на відповідних органах панелі керування.

Початкові дані по каналах задаються через вхідні кластери даних 1. Далі сигнали потрапляють на блоки активації каналів 2, якщо канал активовано то блок активації пропускає дані з вхідного кластера до блоку регулювання 3, якщо не активовано на блок регулювання подається нейтральний сигнал, який не потрібно регулювати (початкове $\mathrm{X}[\mathrm{n}]=\mathrm{X}[0]$; зовнішнє збурення $\mathrm{C}[\mathrm{n}]=0$ ).

Вихідні дані потрапляють на індикатори 4, та на блоки формування вихідних графіків 5.

Блок порівняння та перемикання керуючого впливу відслідковує величини сигналу X[n] та порівнює ї з X[0], і відповідно до заданого кроку перемикання формує булевий масив даних за умовою: активний канал = [TRUE] решта 
«Системні технології» 2 (133) 2021 «System technologies»

каналів $=[$ FALSE], далі через блоки «index array» робиться вибірка сигналу керування на кожен канал.

За формування результатів симуляції відповідають блоки формування вихідних графіків 5 в яких формуються масиви кластерів для відображення графіків всіх каналів на одній діаграмі. Окрім основного завдання програми (відображення на графіку зміни величини X[n] в залежності від різних умов) на діаграму можна вивести сигнал до регулювання, та сигнал керуючої дії, для цього в програму додано «CASE» - структуру 7 за допомогою якої комутується один 3 блоків формування графіків з блоком вивода діаграми.

Також на окремому графіку відображається діаграма роботи керуючого пристрою.

Лицьова панель та блок-діаграма блоку активації каналу даних зображені на Рисунках 7 і 8.

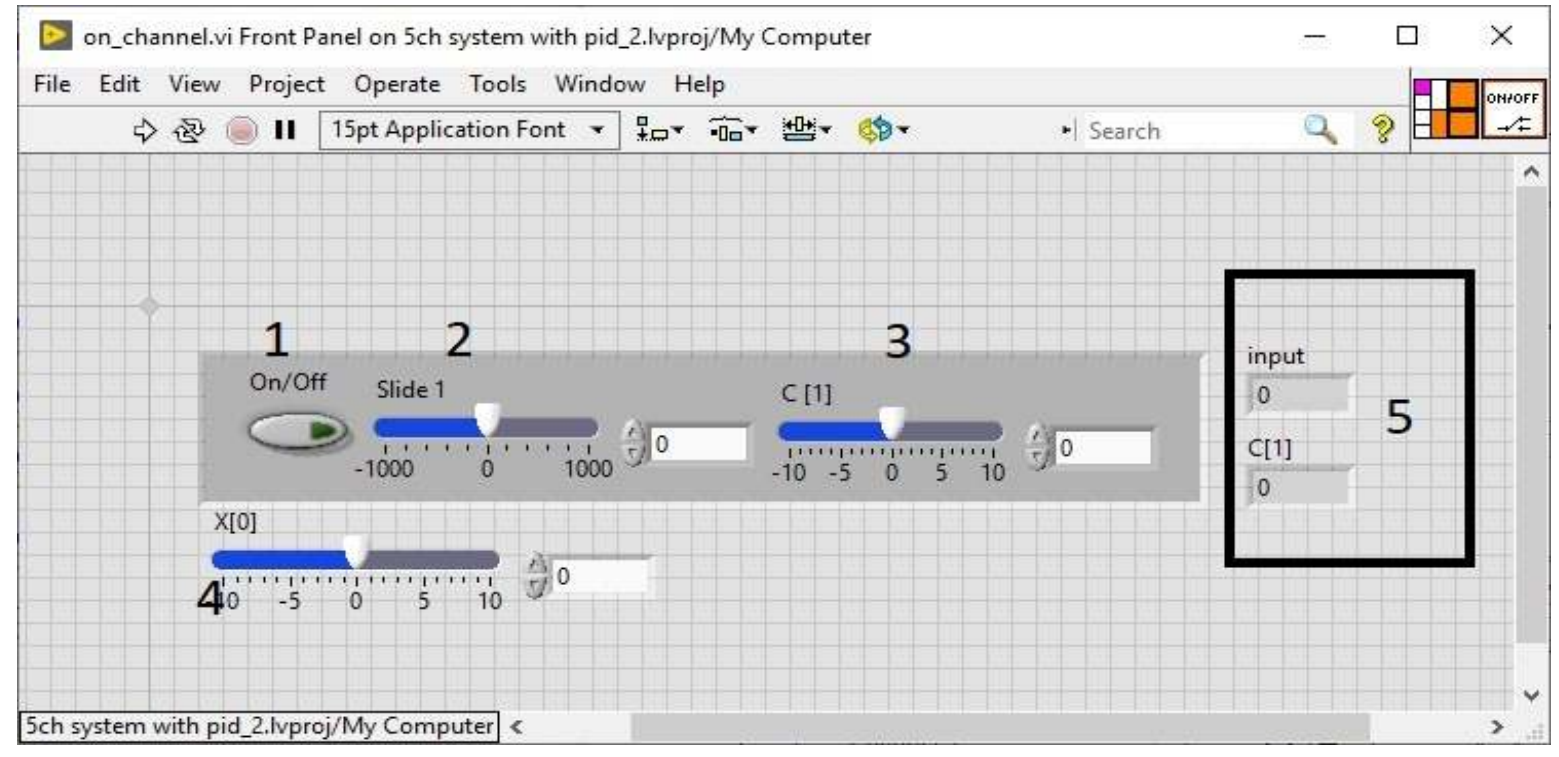

1 - вимикач каналу; 2 - початкова величина сигналу X[n]; 3 - зовнішнє збурення C[n]; 4 - граничне значення Х[0]; 5 - вихідні дані.

Рисунок 7 - Лицьова панель блоку активації каналу даних 
«Системні технології» 2 (133) 2021 «System technologies»

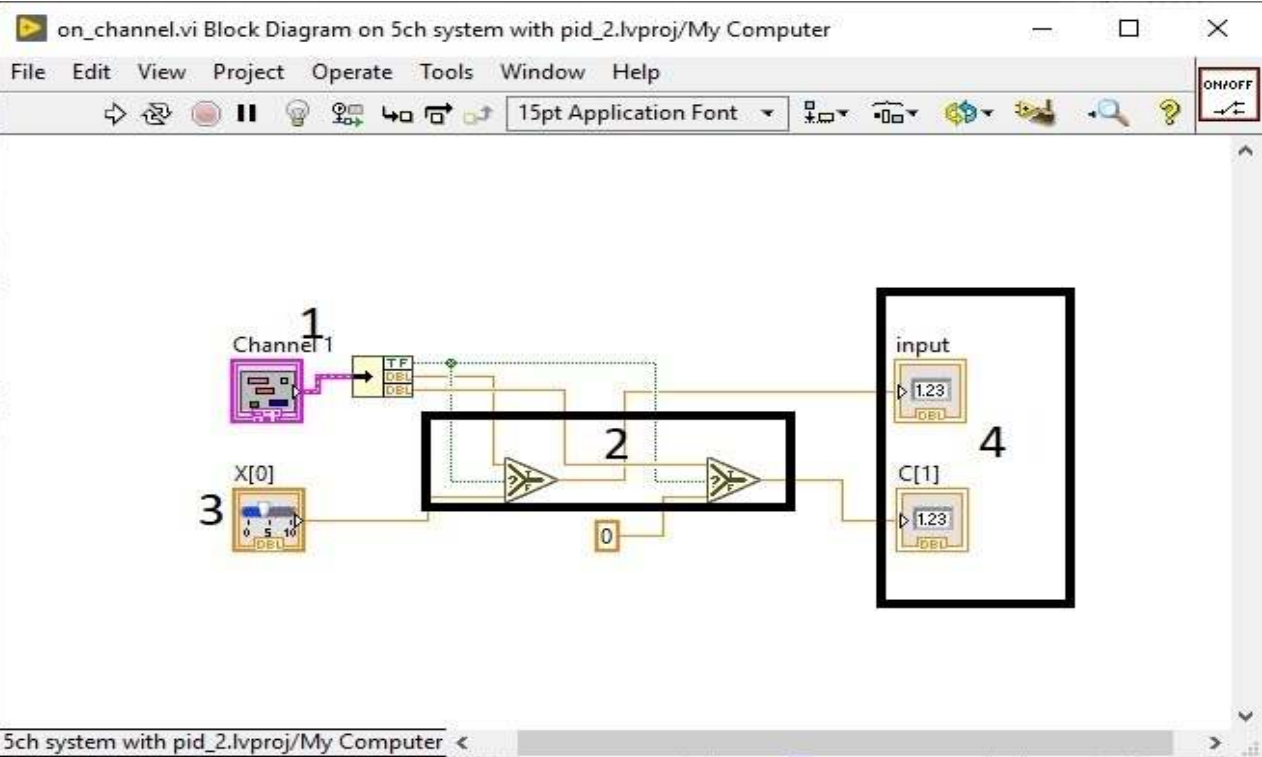

1 - вхідний кластер; 2 - блоки перемикання; 3 - граничне значення Х[0];

4 - вихідні дані.

Рисунок 8 - Блок-діаграма блоку активації каналу даних

Якщо канал ввімкнено, на верхньому виході кластеру з'являється сигнал [TRUE] який потрапляє на перемикачі 2, які комутують сигнали 3 кластеру на вихідні блоки. Якщо канал вимкнено і керуючий сигнал [FALSE], на вихідних блоках комутуються сигнали X[0] та $\mathrm{C}[\mathrm{n}]=0$.

Лицьова панель та блок-діаграма блоку регулювання зображені на РисунKax 9 і 10

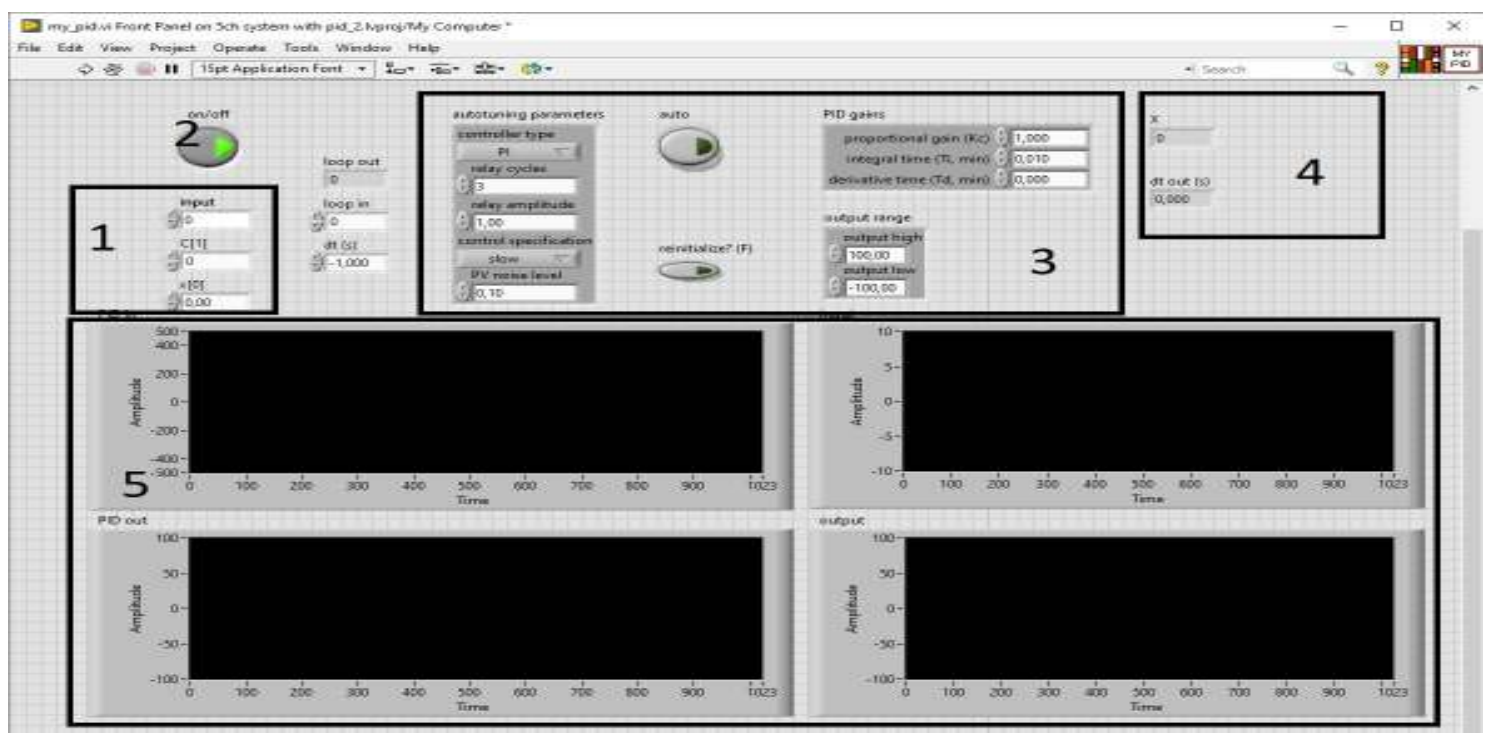

1 - вхідні дані; 2 - вимикач керуючої дії;

3 - налаштування регулятора; 4 - регульований сигнал;

5 - діаграми вхідного, вихідного та керуючих сигналів.

Рисунок 9 - Лицьова панель блоку регулювання 


\section{«Системні технології» 2 (133) 2021 «System technologies»}

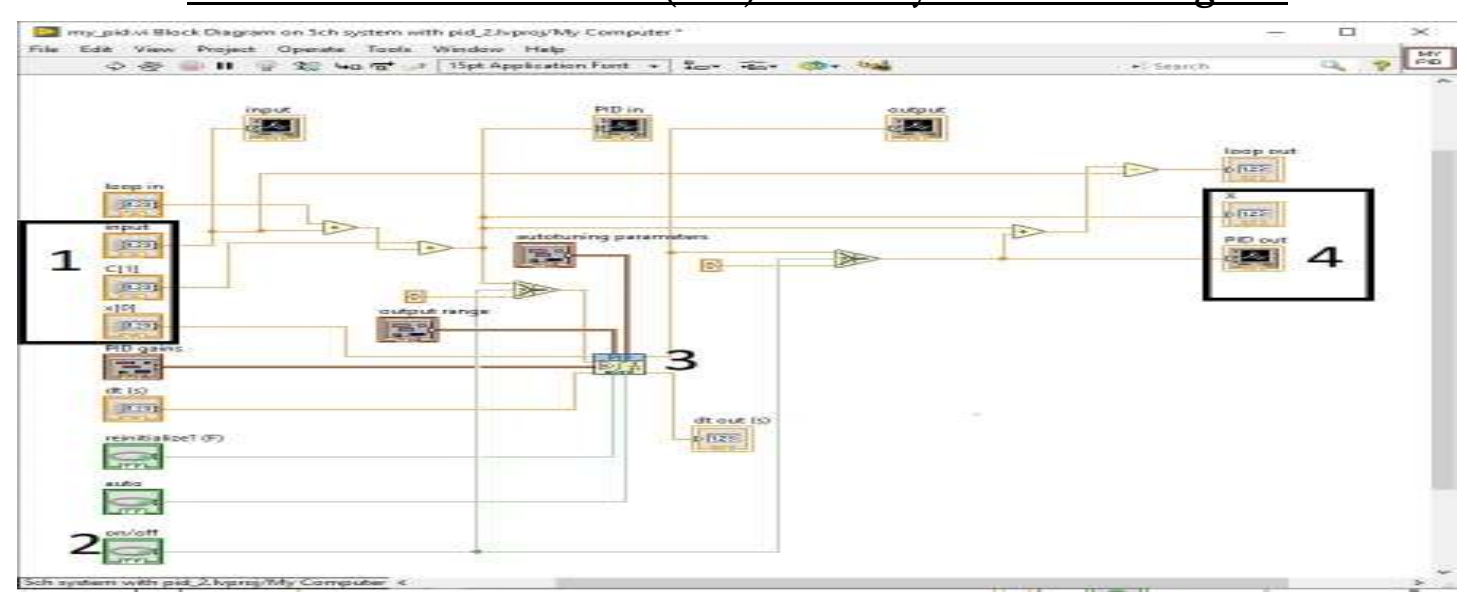

1 - вхідні дані; 2 - вимикач керуючої дії;

3 - регулятор; 4 - вихідні дані

Рисунок 10 - Блок-діаграма блоку регулювання

Вхідний сигнал складається з сигналом зовнішнього збурення, після цього змішаний сигнал потрапляє на вхід PID регулятора, де порівнюється з опорним сигналом X[0]. На виході PID регулятора формується сигнал керуючого впливу, який складається з вхідним сигналом для приведення його до рівня опорного сигналу, та компенсації зовнішніх збурень.

Для того щоб регулятор працював тільки у відведений для цього період а в інший час пропускав сигнал без змін, в схему введено вимикач 2, коли він передає [TRUE] схема працює як було вказано вище, а коли - [FALSE] через перемикачи сигналу, на вхід і вихід PID регулятора подається 0, і змішаний сигнал йде на вихід без змін.

Лицьова панель та блок-діаграма блоку порівняння та перемикання керуючого впливу зображені на Рисунках 11 i 12

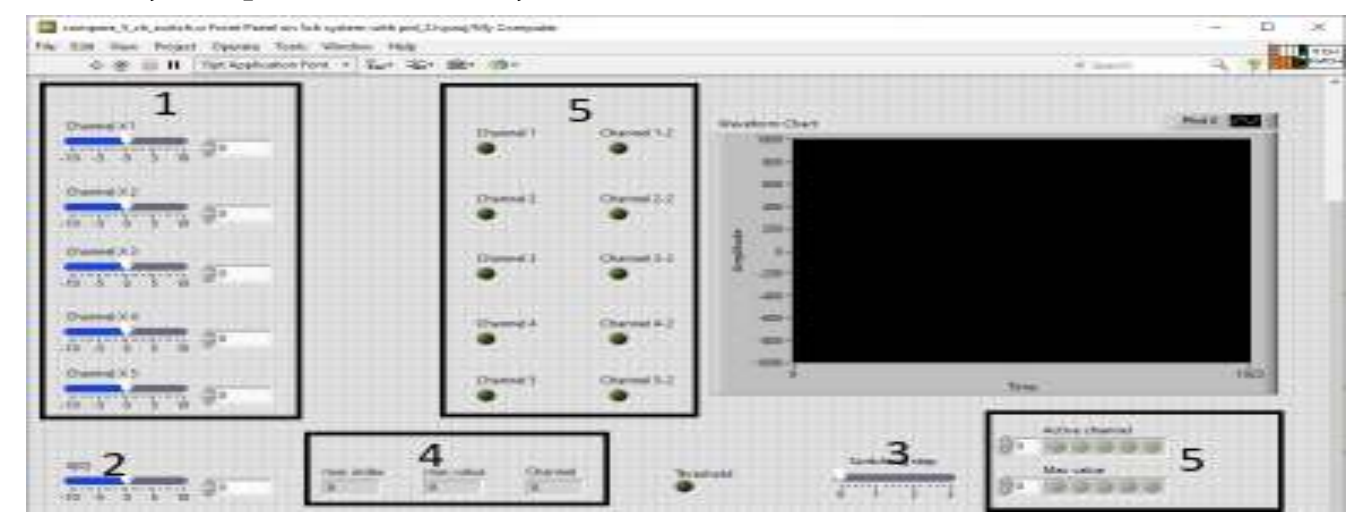

1 - вхідні дані; 2 - опорний сигнал X[0]; 3 - крок перемикання $\Delta[\mathrm{X}]$;

4 - вихідні сигнали; 5 - масив керуючих сигналів.

Рисунок 11 - Лицьова панель блоку порівняння та перемикання керуючого впливу 
«Системні технологіï» 2 (133) 2021 «System technologies»

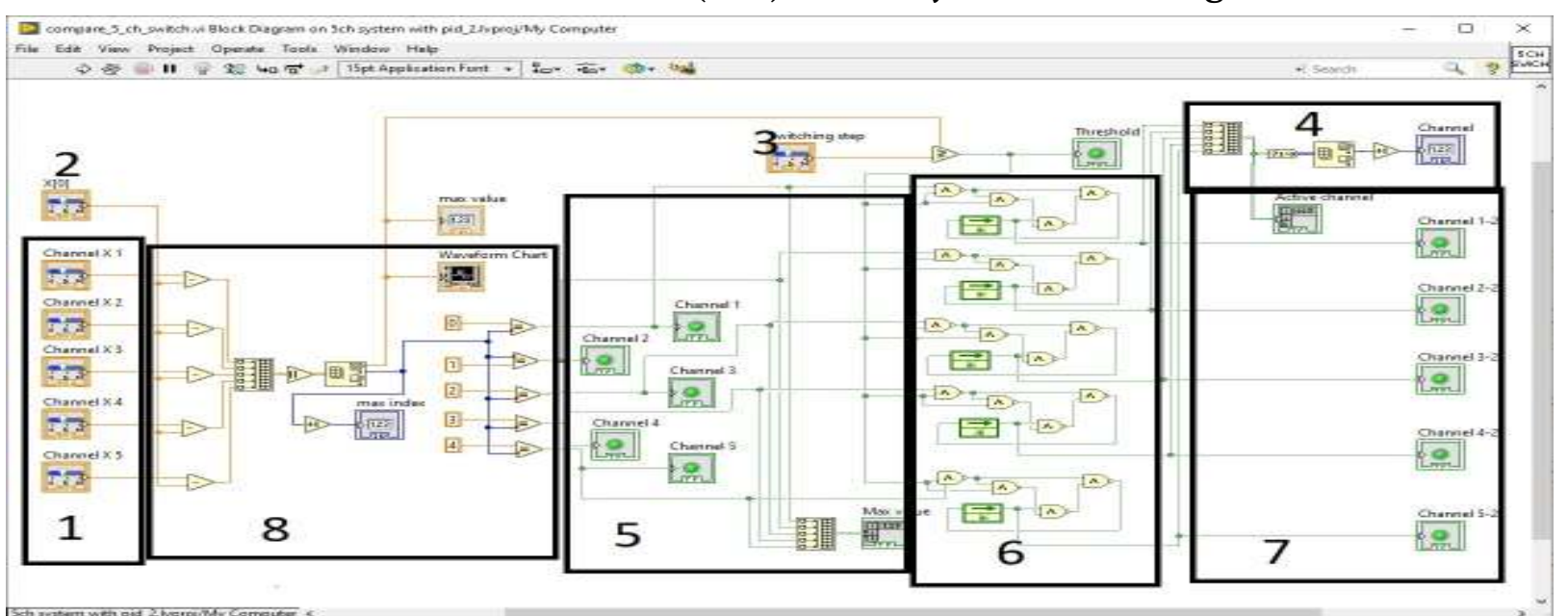

1 - вхідні дані; 2 - опорний сигнал X[0]; 3 - крок перемикання $\Delta[\mathrm{X}]$;

4 - вихідні сигнали; 5 - масив сигналів найбільшого значення; 6 - тригерні блоки; 7 - масив керуючих сигналів; 8 - блок порівняння та визначення максимального відхилення сигналу від опорного.

Рисунок 12 - Блок-діаграма блоку порівняння та перемикання керуючого впливу

Через вхідні термінали 1 сигнали потрапляють в схему, потім з сигналів віднімається величина опорного сигналу, з отриманих даних формується масив відхилень від опорного, потім з цього масиву проводиться вибірка максимального по модулю значення, та індекс каналу, якому це значення належить. Через блоки порівняння номерів каналів з індексом каналу найбільшої величини формується буле вий масив 5 який вказує в якому каналі зараз сигнал найбільшої величини. Потім цей масив потрапляє на тригерні блоки які фіксують значення масиву, доки величина будь якого каналу не перебільшить величину кроку перемикання, після цього в тригерні блоки записується нове значення масиву. Після тригерних блоків масив керуючих сигналів потрапляє на вихідний блок 4, та на блок індикаторів 7.

Лицьова панель та блок-діаграма блоку формування вихідних графіків зображені на Рисунках 13 і 14. 


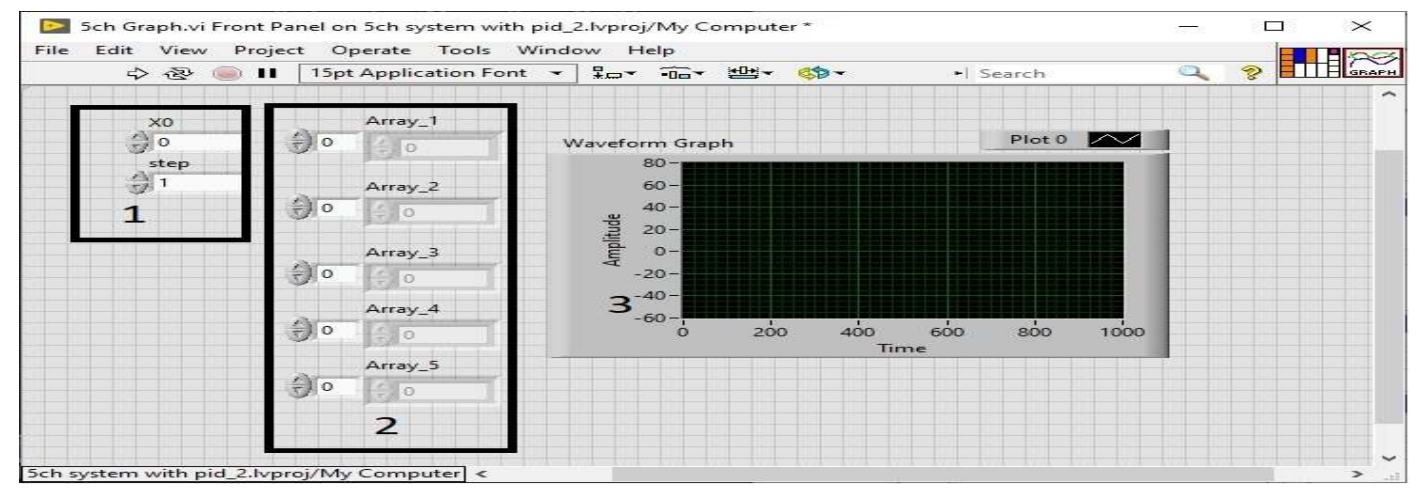

1 - ввід значення початкової точки відліку та кроку дискретизації; 2 - масиви значень сигналу X на кожній ітерації обчислення; 3 - вихідний графік.

Рисунок 13 - Лицьова панель блоку формування вихідних графіків

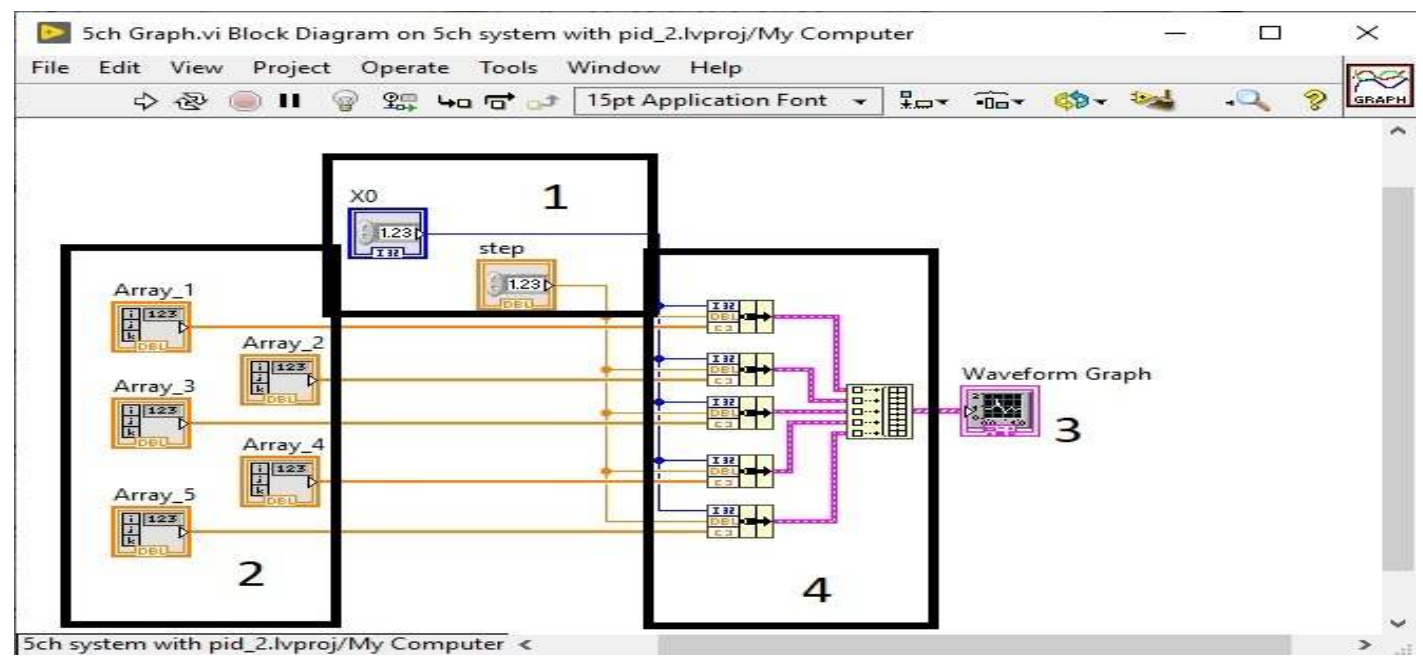

1 - ввід значення початкової точки відліку та кроку дискретизації;

2 - масиви значень сигналу X на кожній ітерації обчислення;

3 - вихідний графік; 4 - об’єднання сигналів.

Рисунок 14- Блок-діаграма блоку формування вихідних графіків

На виході з циклічної структури «For-loop» формуються масиви значень сигналу X окремо по кожному каналу. Для зручного дослідження поведінки системи ці сигнали потрібно відобразити разом на одній часовій діаграмі, для цього і використовується блок формування вихідних графіків.

Щоб відобразити масив даних на часовій діаграмі потрібно сформувати кластер даних, вказавши початкову точку відліку, та крок дискретизації (1) та підключити до нього сам масив(2). Потім з цих кластерів формується масив 4 який виводиться на вихідний термінал 3. 
«Системні технології» 2 (133) 2021 «System technologies»

Перед початком симуляції потрібно включити необхідну кількість каналів перемикачами On/Off, Задати початкові величини сигналів X та зовнішнього збурення С.

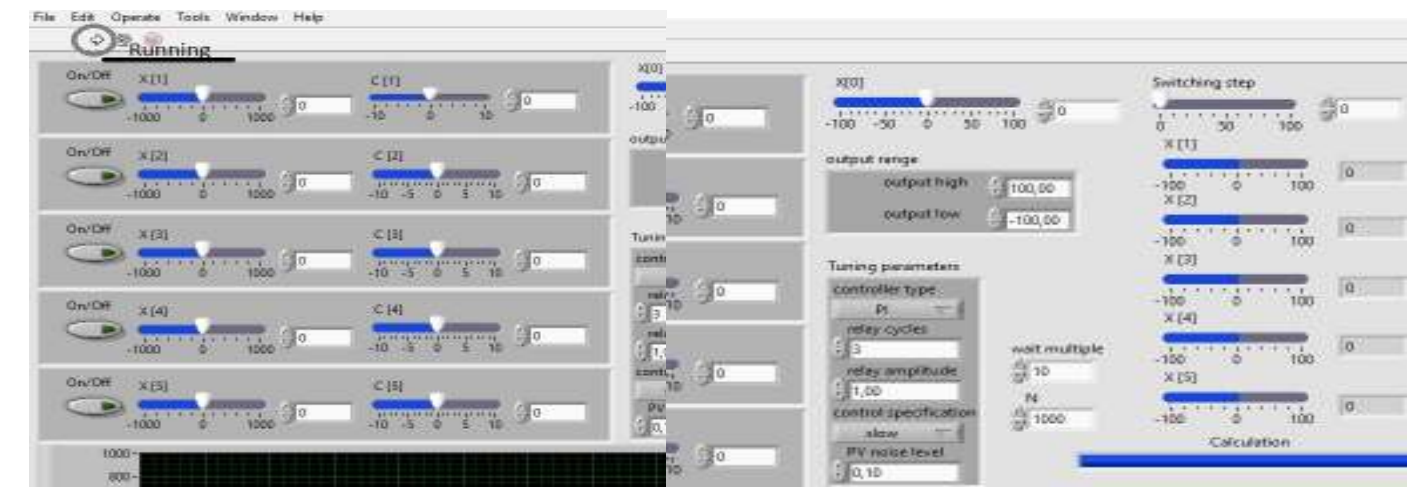

Рисунок 15 - Ввід початкових даних

Щоб задати умови симуляції системи потрібно вказати величини граничного сигналу Х[0], кроку перемикання «Switching step», максимальної величини керуючого впливу «Output range». Також за необхідності можна змінити затримку між ітераціями «wait multiple», та кількість ітерацій симуляції «N», а також тонкі налаштування PID регулятора «Tuning parameters».

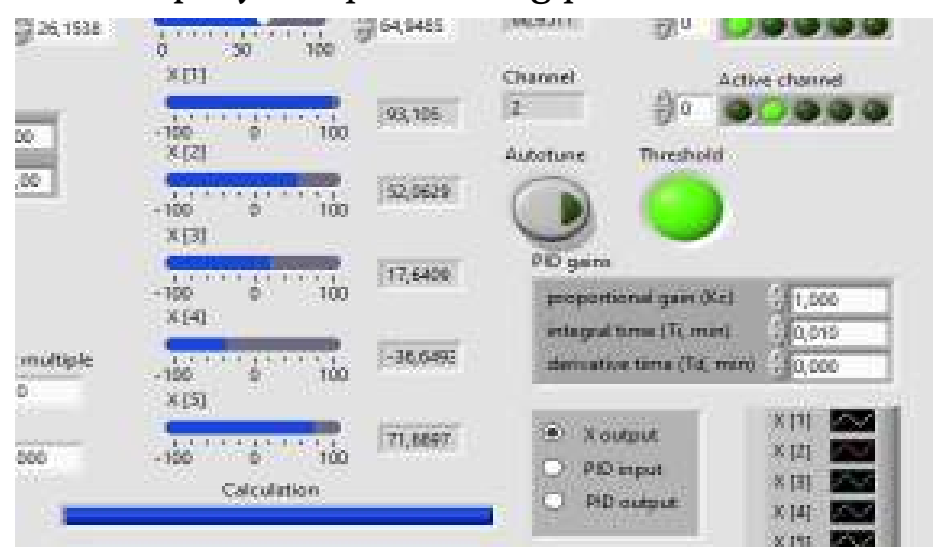

Рисунок 16- Індикатори поточних значень

Після вводу початкових даних та умов симуляції потрібно натиснути на кнопку «Running» з зображенням стрілки. Після цього почнеться симуляція, за якою можна спостерігати по зміні показань індикаторів X[1]...Х[5], значенню активного каналу «Active channel». Та прогрес бару перебігу симуляції «Calculation».

Після закінчення симуляції ми отримаємо 2 графіки (див. Рисунок 17): зміну значення сигналу по кожному каналу на протязі симуляції (1), та перемикання керуючої дії з каналу в канал (2). 


\section{«Системні технології» 2 (133) 2021 «System technologies»}

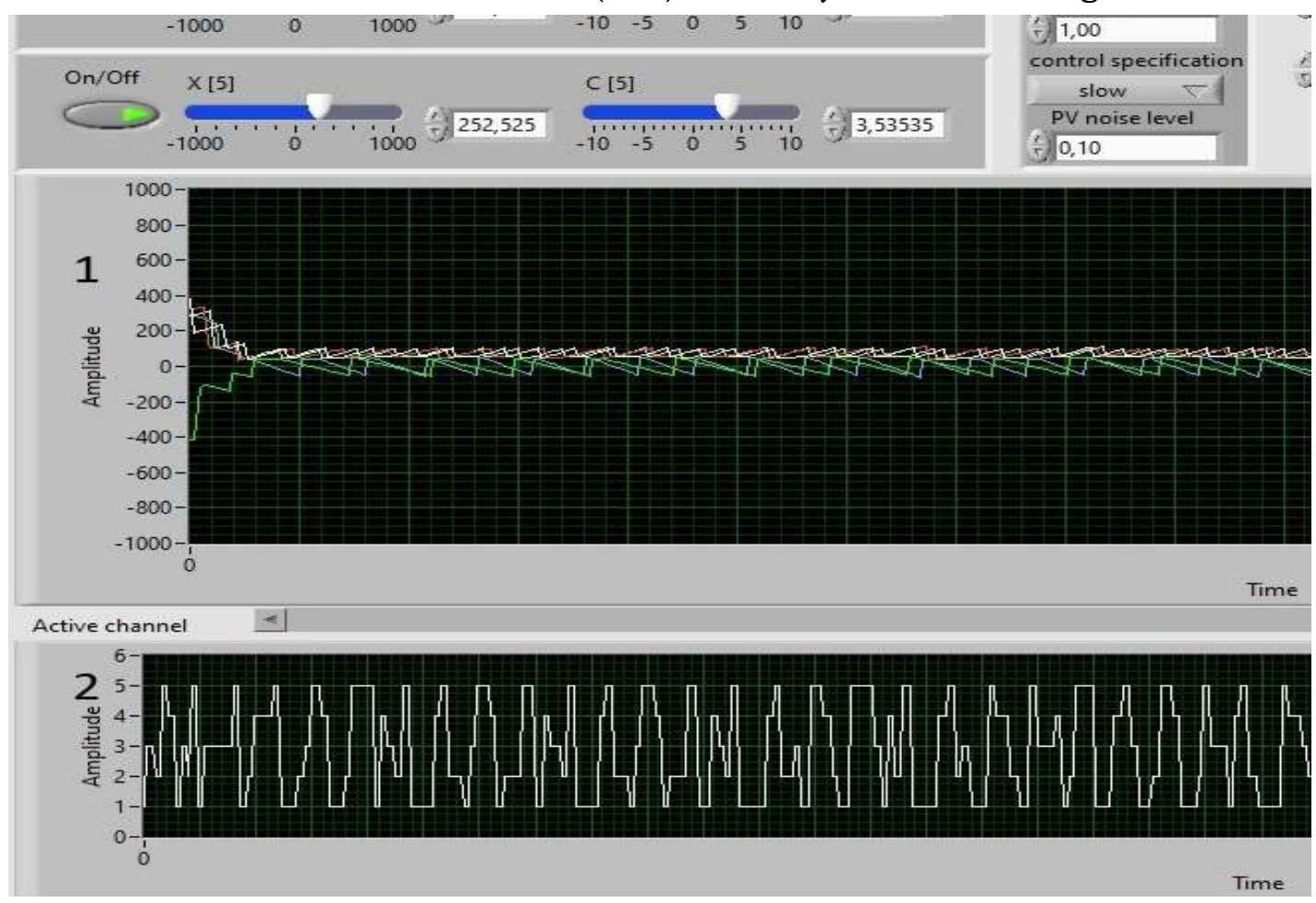

1 - значення сигналу Х по кожному каналу;

2 - перемикання керуючої дії з каналу в канал

Рисунок 17 - Результати досліджень

\section{ЛІТЕРАТУРА / ЛИТЕРАТУРА}

1. Компьютерное моделирование в среде Matlab и LabVIEW: методические указания к лабораторным работам /В.А. Зуев; Январев С.Г. Южно-Российский государственный политехнический университет (НПИ) имени М.И. Платонова Новочеркасск: ЮРГПУ(НПИ), 2015. - 31с.

2. А.А. Воронов. Элементы теории автоматического регулирования. - Москва: Издательство министерства обороны Союза ССР, 1954. - 471с.

3. Соседка В.Л., Соседка Е.В., Соседка Ю.В. Локальные системы автоматики и следящий электропривод. - Донецьк: Східний видавничий дім, 2007. - 224c.

\section{REFERENCES}

1. Computer modeling in the Matlab and LabVIEW environment: guidelines for laboratory work / V.A. Zuev; Yanvarev S.G. South-Russian State Polytechnic University (NPI) named after M.I. Platonov - Novocherkassk: YRSPU (NPI), 2015.31p.

2. A.A. Voronov. Elements of the theory of automatic regulation. - Moscow: Publishing house of the Ministry of Defense of the USSR, 1954. - 471s.

3. Neighbor V.L., Neighbor E.V., Neighbor Yu.V. Local automation systems and electric servo drives. - Donetsk: Skhidny Vidavnichy Dim, 2007. - 224s. 


\section{«Системні технології» 2 (133) 2021 «System technologies»}

\section{Исследование багатоканльних систем поочередного управления}

Существуют САУ с достаточно сложной структурой, имеющие несколько, в различной степени связанных между собой, каналов управления и один общий исполнительный или решающий элемент. Чаще всего, это САУ, в которых переключение происходит при выполнении некоторых условий, называемыми условиями переключения или же САУ, в которой каждый канал снабжен исполнительным элементом, но включение их одновременно невозможно из-за взаимного влияния каналов или же из-за других причин. То есть в названных системах одновременное формирование управляющего воздействия в различных каналах -невозможно. Выбор канала обусловлен законом переключения, вид которой обусловлен решаемой задачей. Закон переключения может быть: по отклонению регулируемой величины; по времени; комбинированный (т.е. по отклонению и времени). Компьютерное моделирование системы было выполнено в интерактивной среде LabVIEW. Приведенна цифровая имитационная модель Мспу и результаты ее исследований.

\section{Investigation of multi-channel systems of alternating control}

There are ACS with a rather complex structure, which have several, to varying degrees of interconnection, control channels and one common executive or decisive element. Most often, these are ACS, in which switching occurs when certain conditions are met, called switching conditions or ACS, in which each channel is equipped with an actuator, but turning them on at the same time is impossible due to the mutual influence of channels or due to other reasons. That is, in these systems, the simultaneous formation of a control action in different channels is impossible. The choice of the channel is determined by the switching law, the type of which is determined by the problem being solved. The switching law can be: by the deviation of the controlled value; by time; combined (i.e. by deviation and time). Computer simulation of the system was performed in an interactive LabVIEW environment. A digital simulation model of MACS(multichannel alternating control system) and the results of its research are presented.

Станчиц Георгій Юрійович - старший викладач кафедри інформаційних технологій та систем Національної металургійної академії України.

Станчиц Антон Георгійович - аспірант кафедри інформаційних технологій та систем Національної металургійної академії України.

Румянцев Олексій Віталійович- студент кафедри інформаційних технологій та систем Національної металургійної академії України.

Станчиц Георгий Юрьевич - старший преподаватель кафедры информационных технологий и систем Национальной металлургической академии Украины. Станчиц Антон Георгиевич - аспирант кафедры информационных технологий и систем Национальной металлургической академии Украины.

Румянцев Алексей Виталийович- студент кафедры информационных технологий и систем Национальной металлургической академии Украины.

Stanchyts George - Senior Lecturer of the Department of Information Technologies and Systems of the National Metallurgical Academy of Ukraine.

Stanchyts Anton - post-graduate student of the Department of Information Technologies and Systems of the National Metallurgical Academy of Ukraine.

Rumianstev Alex - student of the Department of Information Technologies and Systems of the National Metallurgical Academy of Ukraine. 